\title{
Teologi Kebangkitan: Mengkaji Kembali Pemikiran Wolfhart Panenberg Tentang Kebangkitan
}

\author{
Tolop Oloan Marbun \\ Sekolah Tinggi Pelita Dunia Tangerang \\ tolopmarbun@gmail.com
}

\begin{abstract}
This article examines the theology of resurrection: rethinking the thought of Wolfhart Pannenberg about resurrection. Resurrection is the centre of Pannenberg theology. In his views, the bible should be approached in a historical approach and the resurrection is the climax of incarnation since the incarnation was progressive. The method is a qualitative method with a literature approach. The author will describe Pannenberg's thought, after that the author will evaluate his thought, and last the author will give argumentations. As the result, histories were written in the bible because of revelation, the resurrection was not the climax of the incarnation. Bible did not agree with the progressive incarnation, and the death of Jesus was not a catastrophe. The conclusion, Bible should be approached in a revelation approach, Jesus as fully God from eternity to eternity. Bible does not have internal testimony that incarnation was progressive. The death of Jesus is penal substitution.
\end{abstract}

Keywords: incarnation; penal substitution; resurrection; revelation; the death

\begin{abstract}
Abstrak
Artikel ini membahas tentang Teologi Kebangkitan: Mengkaji ulang pemikiran Wolfhart Pannenberg tentang kebangkitan. Kebangkitan merupakan sentral dari teologi Pannenberg. Dalam pandangan Pannenberg, Alkitab harus dipelajari dengan pendekatan historis dan kebangkitan merupakan klimaks dari inkarnasi. Metode yang digunakan metode kualiatas dengan pendekatan studi Pustaka. Pertama penulis akan deskripsikan pemikiran Pannenberg, selanjutanya penulis akan mengkaji ulang pemikirannya dan terakhir penulis akan memberikan argumentasi. Hasilnya, sejarah ditulis dalam Alkitab karena pewahyuan, kebangkitan bukan klimaks inkarnasi, Alkitab tidak menyetujui inkaranis progresif dan kematian Yesus Kristus bukan sebuah catastrophe. Kesimpulannya, mempelajari Alkitab harus menggunakan pendekatan wahyu, Yesus Kristus adalah Allah dari kekekalan sampai kekekalan, Alkitab tidak memiliki kesaksian internal mengenai inkarnasi progresif, dan kematian Yesus adalah penal substitusi.
\end{abstract}

Kata Kunci: inkarnasi; kebangkitan; kematian; penal substitusi; wahyu

\section{Pendahuluan}

Wolfhart Pannenberg seorang teolog Jerman yang lahir di Polandia pada tanggal, 2 Oktober 1928 dan meninggal pada tanggal 5 Mei 2014. Pannernberd dibatis di Gereja Lutheran. Pannenberg mengalami pengelaman religious yang berkesinambungan, Pannenberg menyebutnya dengan istilah "pengalaman ringan". Pengalaman ringan berarti pengalaman awal Pannenberg mencari kebenaran religus. Sejak usia enambelas tahun, Pannenberg mulai belajar dari filsuf-filsuf terkemuka dan pemikir religius (Wolfhart Pannenberg, n.d.). 
Pannenberg mengambil Studi di Univeristas Berlin, Univeritas Gottigen, Universitas Heidelberg dan Universitas Basel. Ketika Pannenberg menulis disertasinya, Pannenberg dibimbing langsung oleh Karl Barth. Dalam proses pembimbibingan tersebut, Pannenberg mendapat banyak pengaruh dari pemikiran Barth. Selain dari Barth, Panneberg juga mendapat pengaruh dari Goerg W.F. Hegel dalam kerangka berpikir (Frame, 2015)Pannenberg merupakan seorang professor teologi sistematika di University of Munich Jerman (Enns, 2015).

Pannenberg dikenal sebagai seorang teolog hisotorisis. Pannenberg mengadakan pendekatan terhadap Alkitab secara historis. Menurut Pannenberg Allah berkarya dalam sejarah dan sejarah tidak ciptakan oleh manusia. Sejarah terjadi secara natural dari setiap tidakan manusia. Dalam Sejarah tersebut ada providensi Allah. Providensi Allah ini tidak hanya untuk memelihara sejarah tetapi juga untuk menjadi panduan sejarah (Pannenberg, 2004). Teologinya disebut teologi historisis. Sebutan ini ditujukan kepada Pannenberg karena dalam berteologi Pannenberg melakukan pendekatan historis. Menurut Pannenberg sejarah adalah pewahyuan Allah (Frame, 2015)

Menurut Panenberg pewahyuan tidak langsung berasal dari Allah. Pewahyuan hadir secara tidak langsung melalui setiap sejarah. Jadi setiap sejarah memiliki wahyu Allah. Wahyu dalam setiap sejarah dapat dipahami oleh setiap orang orang. Oleh sebab itu Pannenberg menegaskan bahwa sejarah penting untuk satu iman yang sah (Enns, 2015). Secara umum ada dua pendekatan Kristologi, Kristologi dari atas ke bawah dan Kristologi dari bawa ke atas. Kristologi dari atas ke bawah memulai kekekalan, KeAlllah Yesus Kristus dari pre-eksisten dan tugas-Nya sebagai Mesias. Dalam pendekatan ini, Pannenberg memilih dengan pendekatan dari bawah ke atas. Pannenberg menekankan teologinya pada kebangkitan. Itulah sebabnya disebut teologi kebangkitan.

Kebangkitan menjadi sentral dari Kristologi Pannenberg, sekalipun demikian ada beberapa hal yang perlu dikaji ulang: pertama, Pannenberg lakaukan pendekatan Kristologinya dari persfektif sejarah Menurut Pannenberg sejarah adalah wahyu karena Allah juga menyatakan diri dalam setiap sejarah (Frame, 2015). Penyataan Allah dalam tindakan historis-Nya menyatakan bahwa Dia adalah Pencipta, Pendamai, dan Penyelamat (Enns, 2014), demikian juga Kristologi dinyatakan lewat sejarah dan lewat sejarah tersebut seseorang bisa mengenal Yesus Kristus.

Kedua, menurut Pannenberg, Yesus Kristus menjadi Allah karena kebangkitanNya (Pannenberg, 2002). Pannenberg meragukan kelllahian Yesus Kristus dari sejak kelahiran-Nya. Menurut Panenberg puncak kelllahian Yesus pada kebangkakitan, disisi lain, Panenberg juga kurang setuju jika seseorang mengatakan bahwa Yesus mendapat KeAllahnnya dari kebangkitannya. Ketiga, Menurut Pannenberg Inkarnasi Yesus Kristus bersifat progresif. Inkarnasi Yesus belum sempurna pada saat kelahiran, termasuk pada masa pelayanan Yesus Kristus. Karena Inkarnasi Yesus Kristus bersifat progresif, maka kesempuranan inkaransi Yesus pada saat kebangkitannya. Dengan kata lain, tanpa kebangkitan, inkaransi Yesus Kristus tidak akan pernah sempurna.

Keempat, Kematian Yesus adalah kesia-sia dan kerugian besar kepada murid-Nya dan diri-Nya sendiri, kebangkitan-Nya sebagai konfirmasi tentang pekerjaan-Nya. 
Pannenberg mengunakan istilah "catastrophe" yang berarti peristiwa tragis yang sangat penting dimulai dari kemalangan yang ekstrim hingga pengulingan dan kehancuran total.

Menurut Penulis bahwa keempat pemikiran Pannenberg tersebut merendahkan nilai wahyu Alkitab dan keillahian Yesus Kristus. Wahyu yang tertulis dalam Alkitab langsung dari Allah bukan dari sejarah. Sejarah yang tertulis dalam Akitab karena diwahyukan oleh Allah. Banyak sejarah di pada masa penulisan Alkitab tetapi tidak semua ditulis dalam Alkitab.

Yesus Kristus tetap Allah dari kekekal sampai selama-lamanya. Tidak ada bukti internal Alkitab bahwa keilahian Yesus Kristus bersifat progressif. Sebelum inkarnasi, pada saat inkarnasi sampai kepada kematian Yesus Kristus tetap Allah yang membatasi diri dalam kemanusian-Nya. Kematian Yesus tidak bisa dianggap sebuah kesia-sian kerena Yesus mati menggantikan semua orang berdosa supaya manusia memiliki jalan penebusan dan pembenaran.

\section{Metode}

Metode yang digunakan dalam atikel ini adalah metode kualitatif dengan pendekatan studi pustaka. Ada pun langkah-langkahnya sesebagi berikut: pertama penulis akan memamparkan pandangan Pannenberg dari berbagai buku, kedua penulis mengkaji ulang pemikiran Pannenberg, dan terakhir penulis akan memberikan argumentasi dari persfektif Teologis terhadap pemikiran Panenberg.

\section{Hasil dan Pembahasan}

\section{Sejarah dan pewahyuan}

Dalam Alkitab banyak tertulis peristiwa-peristiwa bersejarah. Peristiwa bersejarah tersebut penting dalam Alkitab. Tidak ada seorangpun yang dapat mengabaikan atau merendahkan peristiwa tersebut karena sudah menjadi sejarah. Setiap sejarah memiliki nilai penting yang sulit disangkali oleh siapapun juga karena sejarah merupakan fakta-fakta yang pernah terjadi. Sekalipun demikian, Alkitab tidak bisa hanya dilihat dari persfektif sejarah (Pannenberg, 1991). Penulisan setiap kitab dalam Alkitab merupakan hasil dari pengilhaman oleh Roh Kudus (Wilkin, 2019). Roh Kuduslah yang mengilhamkan sejarah tersebut dalam Alkitab sehingga penulis Alkitab menuliskannya dalam Alkitab. Bila Roh Kudus tidak mengilhamkan maka penulis kitab tidak akan pernah mencatatnya. Rasul Yohanes menegaskan bahwa banyak tanda-tanda mujizat yang lain yang dilakukan oleh Yesus yang tidak tercatat dalam kitab Yohanes (Zuck \& Bock, 2011). Dengan kata lain, sejarah yang tertulis dalam Alkitab berdasarkan pewahyuan dari Allah.

Kehidupan Yesus Kristus dalam PB harus dinilai dari perspektif Wahyu. Dalam Alkitab terdapat peristiwa atau kejadian yang bisa diperhitungkan sebagai sejarah, tetapi sejarah tidak bisa menjadi nilai tertinggi dari Alkitab. Roh Kuduslah yang mengilhamkan seluruh kehidupan Yesus Kristus yang tertulis dalam Alkitab. Jadi pengilhaman dalam Alkitab adalah pengilhaman yang lansung dari Allah. 
Yesus Kristus Adalah Allah Dari Kekekalan Sampai Kekekalan

Pannerberg menekankan Kristologinya pada kebangkitan Yesus Kristus. Di sisi lain Pannenberg sendiri meragukan kelahiran dari perawan Maria (Frame, 2015) Kelahiran Yesus Kristus sebenarnya menunjukkan kellahian Yesus. Bila meragukan kelahiran Yesus Kristus secara ilahi, maka pemikiran demikianlah yang membuat Pannenberg menyimpulkan bahwa KeIllahian Yesus Kristus bersifat progresif. KeIllahian Yesus Kristus diperoleh pada saat kebangkitannya (Pannenberg, 2002).

Yohanes memulai Injil Yohanes dengan mengikuti pola Kejadian 1:1. Kejadian 1:1 menunjukkan bahwa Allah memulai genealogi penciptaan alam semesta. Dalam Yohanes 1:1 menunjukkan sebuah permulaan bagaimana Allah yang kekal berinkarnasi menjadi manusia. Parsing Yohanes 1:1, en (preposition: pada) arche (noun, dative, feminine, singular: sebuah permulaan) en (verb, imperfect, indicative active, third person, singular: adalah) ho (article, nominative, masculine, singular: artikel tertentu seperti sang) logos (nominative, masculine, singular: perkataan, Firman) kai (conjunction: dan) ho (article, nominative, masculine, singular: artikel tertentu seperti sang) logos (nominative, masculine, singular: perkataan, Firman) en (verb, imperfect, indicative active, third person, singular: adalah) pros (preposition:: bersama-sama ) ton (article, accusative, masculine, singular: dengan) theov (noun, accusative, masculine: Allah) kai (conjunction: dan) Theos (noun, accusative, masculine: Allah) en (verb, imperfect, indicative active, third person, singular: adalah) ho (article, nominative, masculine, singular: artikel tertentu seperti sang) Logos (nominative, masculine, singular: perkataan, Firman) (Hebrew/Greek Interlinier, 2021).

Hasil parsing Yohanes 1:1, Pada sebuah permulaan adalah Sang Firman dan Sang Firman adalah bersama-sama dengan Allah dan Allah adalah sang Firman. Jadi Sang Firman tidak kurang dari Allah, Sang Firman adalah Allah sepenuhnya.

Yohanes menulis kitab Injil Yohanes dalam pimikiran Semitik sekalipun ditulis dalam bahasa Yunani. Dalam sastra semitik, bila seorang penulis mengulang pernyataan tiga kali, penulis menunjukkan kebenaran yang absolut (Wahyu, 2020). Dalam konteks ini Yohanes menunjukkan kepada pembacanya Sang Firman adalah Allah. Sang Firman sehakekat dengan Allah.

Lukas menjelaskan tentang kelahiran Yesus Kristus. Malaikat berkata kepada Maria, "sesungguhnya engkau akan mengandung dan akan melahirkan seorang anak lakilaki dan hendak engkau menamai Dia Yesus. Ia akan menjadi besar dan disebut Anak Allah yang maha tingggi (Lukas 1:30-32). Berdasarkan pernyataan ini Yesus Kristus adalah Anak Allah. Anak Allah pasti konsubtantial dengan Allah Bapa. Jadi mulai dari proses Yesus Kristus dikandung oleh Maria sampai Yesus Kristus bertumbuh dewasa, Yesus Kristus tetap Allah.

Dalam pelayanan Yesus Kristus, Yesus Kristus banyak melakukan tanda-tanda mujizat yang menunjukkan Dia adalah Allah (Baur 2016). Ketika orang-orang Yahudi mempertanyaakan apakah Yesus adalah Allah. Yesus Kristus menjawab dengan cara yang bijaksana. Yesus menjawab "Aku dan Bapa adalah satu" (Yohanes 10:30). Secara tidak 
langsung Yesus menjawab Dia adalah Allah, Dia setara dengan Allah Bapa. Jadi pada masa pelayanan Yesus Kristus, Yesus Kristus tetap Allah sepenuhnya.

Ke-Allah-an Yesus Kristus tetap terbukti mulai dari penderitaan sampai kepada kematian Yesus Kristus. Tidak ada manusia bisa yang bertahan menahan siksaan dari para algojo Romawi. Yesus Kristus dicambuk 39 kali. Setiap cambuk memiliki asesoris benda tajam 12-16 biji, sehingga setiap cambukan akan menarik kulit dan daging. Kemudian diberi makhota duri, sehingga mengakibatkan pendarahan yang banyak. Setiba di Golgota tangan dan kakinya dipaku. Diberi minum air asam. Manusia normal pasti akan mati segera mengalami penderitaan demikian. Yesus Kristus mati setelah menyerahkan nyawa-Nya kepada Allah Bapa (Stott, 2013). Beberapa saat setelah Yesus mati, tabir Allah terbelah dua, kuburan-kuburan terbuka, dan banyak orang-orang kudus yang telah meninggal bangkit yang disertai dengan gempa. Kepala pasukkan dan prajurit-prajutir menjadi takut dan mengakui "Sungguh, Ia ini adalah Anak Allah (Matius 27:51-54). Jadi penderitaan dan kematian Yesus Kristus juga membuktikan bahwa Yesus Kristus adalah Allah.

Pannerberg tidak memiliki keberatan bahwa kebangkitan menunjukkan bahwa Yesus Kristus adalah Allah. Dengan demikian, dari kebangkitan sampai Yesus naik ke Sorga Panenberg mengakui keAllahan Yesus Kristus. Penulis sudah membuktikan bahwa dari kekekalan sampai pada kekekalan Yesus Kristus adalah Allah. Kebangkitan Yesus Kristus merupakan bukti yang paling akhir bahwa Yesus Kristus adalah Allah, bukan bukti satu-satunya.

\section{Alkitab Tidak Menunjukkan Inkaransi Progresif}

Pennenberg melihat inkaransi bersifat progresif. Kesempurnaan inkarnasi ketika Yesus bangkit dari kematiann (Pannenberg, 1994). Pemikiran Pannenberg tentang inkarnasi yang progresif tidak didukung oleh fakta-fakta yang tertulis dalam Alkitab. Tidak ada bukti-bukti kesakasian internal Alkitab yang menunjukkan ikarnasi Yesus bersifat progresif. Berdasarkan konteks Yohanes 1:1-12 tidak ada "kata" atau "frasa" atau "kalimat" yang menunjukan inkaransi belum sempurna sebelum kembangkitan-Nya. Secara gramatika, tense yang digunakan dalam Yohanes 1:12 mengunakan tenses aorist artinya peristiwa inkarnasi sudah selesai sempurna sekalipun tidak menggunakan keterangan waktu yang spesifik (Maunce, 2011). Kesaksian internal Alkitab, inkaransi Yesus sempurna pada saat Yesus dilahirkan sebagai manusia. Kebangkitan bukan klikmaks dari Inkaransi Yesus, melaikan bukti keAllahan Yesus Kristus yang unik dan tidak bisa dilakukan oleh manusia biasa.

\section{Kematian Yesus Kristus Bukan Sebuah Kerugian}

Allah memberikan perintah kepada Adam, "semua pohon di taman ini boleh kau makan buahnya dengan babas, tetapi pohon pengetahuan yang baik dan yang jahat itu, jangan kau makan buahnya, sebab pada hari engkau memakannya, pastilah engkau mati (Kejadian 2:16-17). Faktanya, Adam dan Hawa memakan buah pengetahuan yang baik dan jahat, seharusnya Adam dan Hawa mengalami kematian pada saat itu. Tetapi karena 
Allah kasih Allah kepada Adam dan Hawa, Allah mengantikan dengan hewan (Kejadian 3:21). Disinilah terjadi penal substitusi yang pertama (Wahyu, 2020) dimana Allah mengorbankan nyawa hewan sehingga nyawa Adam dan Hawa selamat.

Penal substitusi yang pertama ini menjadi tipologi terhadap kematian Yesus Kristus di kayu salib. Upah dosa adalah maut (Roma 6:23) dan semua orang telah berbuat dosa (Roma 3:23) oleh sebab itu semua manusia berdosa harus mengalami maut atau kematian. Kata "mati" ditejemahkan dalam Alkitab Septuaginta Kajadian 2:17 sama dengan kata "maut" dalam Roma 6:23 yaitu thanatos. Semua orang seharusnya mengalami kematian yang kekal karena dosa.

Semua orang seharusnya mengalami maut, tetapi Allah menjadikan Yesus Kristus sebagai penal substitusi. Yesus Kristuslah yang menanggung maut di kayu salib, sehingga setiap orang yang percaya kepada Yesus Kristus tidak perlu mengalami maut atau kematian yang kekal (Geisler, 2011). Kematian Yesus Kristus bukan sebuah kerugian. Kematian Yesus Kristus sangat penting dalam karya keselamatan. Yesus Kristus mengantikan setiap orang berdosa menanggung murka Allah sehingga manusia diperdamaikan dengan Allah.

Yesus Kristus harus tetap melalui kematian, dengan demikian, kebangkitan bisa terjadi (Davidson \& Rae, 2011). Kristus tidak pernah mengalami kebangkitan tanpa kematian. Dengan demikian, kematian Kristus tetap merupakan bagian penting dari keselamatan. Validasi perkataan Yesus Kristus dan karya keselamatan yang Yesus Kristus kerjakan terjadi pada saat kebangkitan. Dengan kata lain, kematian Yesus Kristus langkah menunju validasi perkataan Yesus dan karya keselamatan. Dengan demikian tidak ada Kesia-kesiaan dalam kematian Yesus Kristus.

\section{Implikasi}

Ada banyak sejarah yang tertulis dalam Alkitab, sekalipun demikian, teolog tidak bisa menafsirkan Alkitab secara historisis dan mengabaikan peran Roh Kudus dalam pengilhaman Alkitab. Sejarah tidak bisa melahirkan wahyu, sebaliknya, pehwahyuan yang memberikan ruang kepada sejarah sehingga tertulis dalam Alkitab. Dalam mempelajari Kristologi, teolog harus melihat firman TUHAN secara komprehensif, teolog tidak bisa menasifrkan sebagaian saja untuk meminimalisir penafsiran yang keliru. Penafsiran yang keliru menghasilkan pengajaran yang yang keliru. Pengajaran yang keliru menghasilkan kesesatan. Teolog tidak bisa memisahkan kematian dan kebangkitan Kristus. Kematian dan kebangkitan Kristus seperti dua sisi mata uang yang berbeda tetapi saling melengkapi. Dalam konteks soteriologi, kematian dan kebangkitan Kristus merupakan karya Kristus yang mendatangkan keselamatan bagi semua orang.

\section{Rekomendasi untuk Penelitian Lanjutan}

Panenberg dikenal sebagai teolog historisisi karena pendekatannya lewat sejarah. Penulis merekomendasikan untuk pemikiran lanjutan tentang kaian julang pemikiran panenberg terhadap otoritas Alkitab. Panenberg menilai otoritas Alkitab terletak pada sejarah. Allah menyatakan pewahuan lewat sejarah-sejarah yang tertulis dalam Alkitab. 
Pemikiran Panenberg menimbulkan pernyataan bagaimana mungkin seorang teolog berteologi berdasarkan Alkitab sementara di sisi lain teolog tersebut meragukan Alkitab, termasuk meragukan Yesus Kristus lahir dari perawan Maria.

\section{Kesimpulan}

Alkitab dan kehidupan Yesus Kristus tidak bisa dinilai dari perspektif sejarah atau secara horizontal. Kehidupan Yesus Kristus yang tertulis dalam Alkitab merupakan hasil ilham dari Roh Kudus. Meskinpun masih banyak tanda-tanda mujizat yang tidak tertulis dalam Alkitab, Roh Kudus hanya mengilhamkan sebagian saja dan tanda-tanda mujizat tersebut cukup untuk membawa seseorang untuk memercayai Yesus Kristus sebagai Tuhan. Yesus Kristus adalah Allah dari kekekalan sampai kekekalan. Yesus Kristus adalah Sang Firman yang berinkarnasi menjadi manusia. Proses kelahirannya membuktikan Yesus Kristus adalah Allah. Pelayanan Yesus Kristus membuktikan bahwa Dia adalah Allah. Penderitaan dan kematian-Nya membuktikan Yesus Kristus adalah Allah. Kebangkitan-Nya merupakan puncak bukti KeAllahan-Nya. Kenaikan-Nya ke sorga juga membuktikan bahwa Yesus Kristus adalah Allah. Jadi semua rangkaian kehidupan Yesus mulai dari Nubutan kelahiran-Nya sampai kembali ke sorga membuktikan Yesus Kristus adalah Allah.

Tidak ada bukti internal atau kesaksian Alkitab sendiri bahwa inkaranasi bersifat progresif. Alkitab tidak membenarkan bahwa kebangkitan Yesus Kristus merupakan klimaks dari Inkarnasi. Secara gramatikal, Inkarnasi Yesus Kristus sempurna ketika Yesus Kristus lahir sebagai manusia. Kematian Kristus tidak bisa diperhitungkan sebagai Kesiasiaan apalagi disebut sebagai "catastrophe." Kematian Kristus sebagai penal substitusi. Kristus mati mengantikan semua orang berdosa. Semua orang berdosa seharusnya mengalami kematian kekal. Oleh karena kasih-Nya, Yesus Kristus rela mati mengantikan semua orang berdosa, sehingga manusia tidak perlu mengalami kematian yang kekal, melainkan beroleh kehidupan yang kekal.

\section{Rujukan}

Davidson, I. J., \& Rae, M. A. (2011). God of Salvation. Esgate.

Enns, P. (n.d.). The Moody Handbook of Theology: Revised and expanded (2015th ed.). Moody Publisher.

Frame, J. M. (2015). A History of Western Philosophy and Theology. P\&R Publishing.

Geisler, N. (2011). Systematic Theology: In One Volume. BethanyHouse.

Hebrew/Greek Interlinier. (2021). Hagios Tech.

Pannenberg, W. (1991). Systematic Theology (Vol. 1). Eerdmans.

Pannenberg, W. (2002). Jesus- God and Man. SCM Press.

Pannenberg, W. (2004). Antrophology In Theological Persfective. T\&T Carlk International. Wahyu, R. (2020). Eksegesis Peshat Kitab Kejadian- Kitab Genealogi, Kejadian 1:1-6:8 (2nd ed.). Ekumene Literatur.

Wilkin, R. N. (Ed.). (2019). The Grace New Testament Commentary. Grace Evangelical Society. 
Wolfhart Pannenberg. (n.d.). [Blog].

https://www.encyclopedia.com/history/encyclopedias-almanacs-transcriptsand-maps/wolfhart-pannenberg

Zuck, R., \& Bock, D. (Eds.). (2011). A Biblical Theology of New Testament. Dallas Theological Seminary. 